Hydrology and Earth System Sciences, 5(4), 679-691 (2001) C C EGS

\title{
Statistical and trend analysis of water quality and quantity data for the Strymon River in Greece
}

\author{
Vassilis Z. Antonopoulos, Dimitris M. Papamichail and Konstantina A. Mitsiou \\ Depart. of Hydraulics, Soil Science and Agricultural Engineering, School of Agriculture, Aristotle University of Thessaloniki, 54006 Thessaloniki, Greece. \\ Email for corresponding author: vasanton@agro.auth.gr
}

\begin{abstract}
Strymon is a transboundary river of Greece, Bulgaria and Former Yugoslav Republic of Macedonia (FYROM) in southeastern Europe. Water quality parameters and the discharge have been monitored each month just $10 \mathrm{~km}$ downstream of the river's entry into Greece. The data of nine water quality variables (T, ECw, DO, $\mathrm{SO}_{4}{ }_{4}^{2-}, \mathrm{Na}^{+}+\mathrm{K}^{+}, \mathrm{Mg}^{2+}, \mathrm{Ca}^{2+}, \mathrm{NO}_{3}^{-}, \mathrm{TP}$ ) and the discharge for the period 1980-1997 were selected for this analysis. In this paper a) the time series of monthly values of water quality parameters and the discharge were analysed using statistical methods, b) the existence of trends and the evaluation of the best fitted models were performed and c) the relationships between concentration and loads of constituents both with the discharge were also examined. Boxplots for summarising the distribution of a data set were used. The $\chi^{2}$-test and the Kolmogorov-Smirnov test were used to select the theoretical distribution which best fitted the data. Simple regression was used to examine the concentration-discharge and the load-discharge relationships. According to the correlation coefficient (r) values the relation between concentrations and discharge is weak $(r<0.592)$ while the relation between loads and discharge is very strong $(r>0.902)$. Trends were detected using the nonparametric Spearman's criterion upon the data for the variables: $\mathrm{Q}, \mathrm{ECw}, \mathrm{DO}, \mathrm{SO}_{4}^{2-}, \mathrm{Na}^{+}+\mathrm{K}^{+}$and $\mathrm{NO}_{3}{ }^{-}$on which temporal trend analysis was performed.
\end{abstract}

Key words: Strymon river, water quality, discharge, concentration, load, statistics, trends

\section{Introduction}

The water quality of water resources is a subject of ongoing concern. The assessment of long-term water quality changes is also a challenging problem. During the last decades, there has been an increasing demand for monitoring water quality of many rivers by regular measurements of various water quality variables. The result has been the gradual accumulation of reliable long-term water quality records and the examination of these data for long-term trends (Hirsch et al., 1991). According to Liebetrau (1979), some of the necessities of water quality monitoring are the following: 1) to provide a system-wide synopsis of water quality, 2) to monitor long-range trends in selected water quality parameters, 3) to detect actual or potential water quality problems; if such problems exist $3 a$ ) to determine specific causes and $3 b$ ) to assess the effect of any convective action and 4) to enforce standards.
Computer systems now offer the possibility of handling and manipulating very large databases in ways which were not previously a practical option. Littlewood et al. (1998) have used such databases for estimation of UK river mass loads of pollutants. Miller and Hirst (1998) used the hydrochemical databases from an upland catchment in Scotland for a period of five years to assess the annual variation in amounts and concentration of solutes and to examine the variation in streamwater quality due to changes in flow, season and long time trend. Ferrier et al. (2001) analysed in detail databases for Scotland and identified temporal changes in water quality over the last 20 years.

The Strymon River is one of the most important rivers in the Greek and Balkan area, with an extensive basin of 17,330 $\mathrm{km}^{2}$. The water quality and the discharge entering Greece is affected by many different anthropogenic factors and processes taking place in that part of the river catchment 
occupied by Bulgaria and FYROM. Monthly measurements of the discharge and the water quality variables have been monitored at the Sidirokastro Bridge station of the Strymon River by the Greek Ministry of Agriculture. The Sidirokastro Bridge station is $10 \mathrm{~km}$ downstream of the Greek-Bulgarian border and upstream of Kerkini Lake, which is one of the significant wetlands in the area of Balkans.

This paper examines statistically: (1) the time series of monthly values of water quality parameters and the discharge at Sidirokastro station, (2) the existence of trends and the evaluation of the best fitted trend models, and (3) the relationships between concentration and loads of solutes and the discharge.

\section{Methodology for the analysis of water quality parameters}

In planning control and management programme of streams, the statistical and trend analysis as well as the relations between concentrations or loads and discharge are important steps for understanding the behaviour and the variation of water quality parameters and streamflow. This variation is affected by many factors. These factors may be formed by the different substances in the surface water due to activities in the catchment and may be further obscured by random events. Furthermore, the streamflow data exhibit hydrological persistence and seasonal variance (Antonopoulos and Papamichail, 1991).

\section{PROBABILITY DISTRIBUTION OF WATER QUALITY} PARAMETERS

Water quality data do not usually follow convenient probability distributions such as the well-known normal and lognormal distributions on which many classical statistical methods are based (Lettenmaier et al., 1991).

Probability plots are used to determine how well data fit a theoretical distribution. This could be achieved by comparing visually histograms of measured values to the density curve of theoretical distributions.

To select the distribution which provided the best fit, ten theoretical probability distribution functions were examined: Chi-square $\left(\chi^{2}\right)$, Erlang (Er), Exponential (Ex), F, Gamma (G), Logistic (L), Lognormal (LN), Normal (N), Triangular (Tr) and Weibull (W). To select the distribution which fitted the data best, the $\chi^{2}$-test and the Kolmogorov-Smirnov test $(\mathrm{K}-\mathrm{S})$ were used.

The $\chi^{2}$ test compares the measured and the predicted frequencies and it is described by the formula (Haan, 1977)

$$
\chi^{2}=\sum_{i=1}^{k}\left[\frac{\left(o_{i}-e_{i}\right)^{2}}{e_{i}}\right]
$$

where $\mathrm{o}_{\mathrm{i}}$ and $\mathrm{e}_{\mathrm{i}}$ are the measured and predicted frequencies respectively and $\mathrm{k}$ is the number of class intervals. The null hypothesis $\mathrm{H}_{0}$ is that the data follow a theoretical distribution. $\mathrm{H}_{0}$ should be rejected if the statistic $\chi^{2}$ exceeds the $(1-\alpha)$ quantile of a chi-square distribution having $(k-1)$ degrees of freedom.

The K-S test is a non-parametric test (Haan, 1977) of the fitting of data to a theoretical distribution using the maximum absolute deviation (D) between the two functions of cumulative distribution. It is calculated by

$$
\mathrm{D}=\max \mathrm{F}_{\mathrm{n}}(\mathrm{x})-\mathrm{F}_{\mathrm{o}}(\mathrm{x})
$$

where $F_{n}(x)$ is the cumulative density function based on $n$ measurements, $\mathrm{F}_{\mathrm{o}}(\mathrm{x})$ is the specified theoretical cumulative distribution function under the null hypothesis $\mathrm{H}_{0}$. The values of $D(n, \alpha)$ are given in tables (Haan, 1977). If $\mathrm{D} \geq \mathrm{D}(\mathrm{n}, \alpha)$, the $\mathrm{H}_{0}$ hypothesis is rejected and if $\mathrm{D}<\mathrm{D}(\mathrm{n}, \alpha)$, $\mathrm{H}_{0}$ is accepted, for the chosen level of significance $\alpha=0.05$.

\section{SOLUTE CONCENTRATIONS-DISCHARGE AND}

\section{LOADS-DISCHARGE RELATIONSHIPS}

The concentrations of solutes in water in a stream vary during time. A major source of this variation is the stream discharge (Edwards, 1973; Pinol et al., 1992). A strong relationship between streamwater chemistry and discharge at different spatial and temporal scales has been identified for rivers and streams (Larsen et al., 1999).

The load (or flux) of water solutes (the product of discharge and concentration) is an important variable of water quality if interest focuses upon storage of the water and its constituents. The load of relatively conservative constituents may be important where the monitoring station is upstream of a reservoir, lake or estuary where the water has a long residence time and the exposure to chemicals by aquatic organisms or populations that ingest the water is of concern (Hirsch et al., 1991).

Different models were proposed to describe the relationship between concentration-discharge and loaddischarge (Edwards, 1973; Oborne et al., 1980; Pinol et al., 1992). These relationships give information on the variation of quality parameters due to discharge. Hirsch et al. (1982) suggested that, for water quality variables that are highly dependent on stream flow, the confounding effects of discharge variations be removed by analysing the residuals from a discharge-concentration relationship for trend, rather than the raw data. For this analysis, the linear $\left(\mathrm{C}_{\mathrm{ij}}=\mathrm{a}+\mathrm{b} \mathrm{Q}_{\mathrm{j}}\right)$, the power $\left(\mathrm{C}_{\mathrm{ij}}=\mathrm{aQ} \mathrm{Q}_{\mathrm{j}}^{\mathrm{b}}\right)$, the exponential $\left(\mathrm{C}_{\mathrm{ij}}=\mathrm{a} \exp \left(\mathrm{b} \mathrm{Q}_{\mathrm{j}}\right)\right)$, and the logarithmic $\left(\mathrm{C}_{\mathrm{ij}}=\mathrm{a}+\mathrm{b} \ln \left(\mathrm{Q}_{\mathrm{j}}\right)\right)$ models were used. The method of least squares for the pairs of monthly measured 
values of each variable and the discharge was used to determine the constants of these models.

\section{TREND ANALYSIS}

Testing water quality data for trend over a period of time has received considerable attention recently. The interest in methods of water quality trend arises for two reasons. The first is the intrinsic interest in the question of changing water quality arising out of the environmental concern and activity. The second reason is that only recently has there been a substantial amount of data that is amenable to such an analysis.

Trend analysis determines whether the measured values of a water quality variable increase or decrease during a time period. In statistical terms, has the probability distribution from which they arise changed over time? It would be useful to describe the amount or rate of that change, in terms of changes in some central value of the distribution such as mean or median (Hirsch et al., 1982; Hirsch and Slack, 1984).

Hirsch et al. (1982) suggested an adaptation of the Kendall non-parametric test to detect trends in seasonally varying water quality time series; this is often referred to as the seasonal Kendall's test. This test can accommodate time series with missing data. In this study, to detect the existence of trends in the time series of the variables involved, the nonparametric Spearman's criterion was used and different trend models were fitted (Dahmen and Hall, 1990). The Spearman rank-correlation coefficient is described as:

$$
\mathrm{R}_{\mathrm{sp}}=1-\frac{6 \sum_{\mathrm{i}=1}^{\mathrm{n}}\left(\mathrm{D}_{\mathrm{i}} \mathrm{D}_{\mathrm{i}}\right)}{\mathrm{n}\left(\mathrm{n}^{2}-1\right)}
$$

where $\mathrm{n}$ is the total number of values in each time series, $\mathrm{D}$ is the difference and $i$ is the chronological order number. The difference between rankings is computed as $\mathrm{D}_{\mathrm{i}}=\mathrm{Kx}_{\mathrm{i}}$ $\mathrm{Ky}_{\mathrm{i}}$, where: $\mathrm{Kx}_{\mathrm{i}}$ is the rank of a measured variable in chronological order and $\mathrm{Ky}_{\mathrm{i}}$ is the series of measurements transformed to its rank equivalent, by assigning the chronological order number of a measurement in the original series to the corresponding order number in the ranked series, $\mathrm{y}$. The null hypothesis, $\mathrm{H}_{0}: \mathrm{R}_{\mathrm{sp}}=0$ (there is no trend), against the alternate hypothesis, $\mathrm{H}_{1}: \mathrm{R}_{\mathrm{sp}}<$ or $>0$ (there is a trend), is checked with the test statistic:

$$
\mathrm{t}_{\mathrm{t}}=\mathrm{R}_{\mathrm{sp}}\left[\frac{\mathrm{n}-2}{1-\mathrm{R}_{\mathrm{sp}}^{2}}\right]^{0.5}
$$

where $t_{t}$ has Student's t-distribution, with $v=n-2$ degrees of freedom. At a significant level of 5\%, the time series has no trend if:

$$
\mathrm{t}\{\mathrm{v}, 2.5 \%\}<\mathrm{t}_{\mathrm{t}}<\mathrm{t}\{\mathrm{v}, 97.5 \%\}
$$

The trend analysis applied here was an attempt to fit the following linear, quadratic, exponential and mixed type models to the time series of the discharge and the water quality parameters:

$$
\begin{aligned}
& \mathrm{F}=\alpha+\beta \cdot \mathrm{T} \\
& \mathrm{F}=\alpha+\beta \cdot \mathrm{T}+\mathrm{c} \cdot \mathrm{T}^{2} \\
& \mathrm{~F}=\exp (\alpha+\beta \cdot \mathrm{T}) \\
& \mathrm{F}=\exp (\alpha+\beta / \mathrm{T})
\end{aligned}
$$

The best-fitted model of time trend for each variable was chosen using the following statistical criteria of Mean Error (ME), Mean Square Error (MSE), Mean Absolute Error (MAE) and Mean Absolute Percent Error (MAPE) (Makridakis et al., 1986):

$$
\begin{aligned}
& \text { ME }=\sum_{i=1}^{n} e_{i} / n \\
& \text { MSE }=\sum_{i=1}^{n} e_{i}^{2} / n \\
& \text { MAE }=\sum_{i=1}^{n}\left|e_{i}\right| / n \\
& \text { MAPE }=\sum_{i=1}^{n}\left|\left(X_{i}-F_{i} / X_{i}\right) \cdot 100\right| / n
\end{aligned}
$$

where $X_{i}$ is the measured value at time $i, F_{i}$ is the predicted value at the same time, $e_{i}=X_{i}-F_{i}$ and $n$ is the number of measurements. The closer the average ME is to zero and the smaller the values of MSE, MAE and MAPE, the better the model fits the time-series (Statgraphics, 1987).

\section{DESCRIPTION OF STUDY SITE}

The Strymon River, is a transboundary river of Greece, Bulgaria and FYROM. Its length is about $392 \mathrm{~km}$ and after a distance of approximately $118 \mathrm{~km}$ in Greek territory it discharges into the Northern Aegean Sea (Fig. 1). The total area of the Strymon catchment is approximately $17,330 \mathrm{~km}^{2}$ of which $8,670 \mathrm{~km}^{2}(50 \%)$ are in Bulgaria, $2,365 \mathrm{~km}^{2}$ (13.6\%) in FYROM and 6,295 $\mathrm{km}^{2}$ (36.4\%) in Greece. The mean elevation of the catchment is approximately $830 \mathrm{~m}$ while $77 \mathrm{~km}$ upstream of the mouth of the Strymon River a dam was constructed in 1932 forming Kerkini Lake, which is one of the 11 Ramsar sites in Greece. The initial volume of Kerkini Lake was $312 \times 10^{6} \mathrm{~m}^{3}$, which had reduced to 


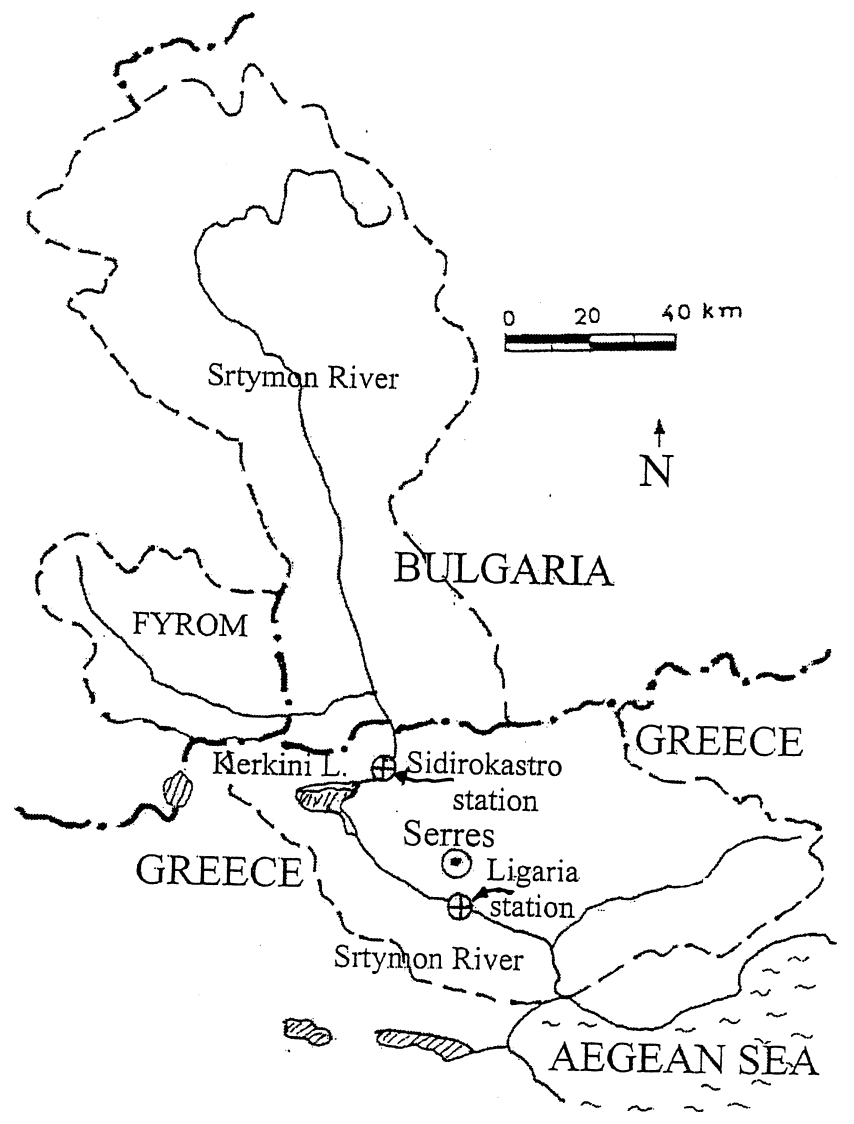

Fig. 1. River Strymon, its catchment boundaries and Sidirokastro water quality sampling station

$170 \times 10^{6} \mathrm{~m}^{3}$ in 1977 . In 1983 a new dam was constructed in the same place. Now the maximum volume of lake rises to $600 \times 10^{6} \mathrm{~m}^{3}$. The main attributes of the lake are flood control, irrigation, fisheries and biodiversity. The Strymon River carries high quantities of sediments and solutes into the lake, affecting the system values negatively.

The mean yearly precipitation in the area of Kerkini lake is $534 \mathrm{~mm}$, with a distribution during the year which follows the two characteristic peaks of a Mediterranean climate. The mean yearly temperature is $15.4{ }^{\circ} \mathrm{C}$, with July the warmest month $\left(26.7^{\circ} \mathrm{C}\right)$ and January the coldest month $\left(3.9^{\circ} \mathrm{C}\right)$.

Upstream of Kerkini Lake and $10 \mathrm{~km}$ downstream of the Greek-Bulgarian border at Sidirokastro Bridge of the Strymon River there is a monitoring station, where the Greek Ministry of Agriculture measures water flow and takes water samples once every month. This station has been included in the European Community's water quality monitoring programme since 1982 (E.C., 1994).

Among the variables measured by the Department of Irrigation and Water Protection of the Greek Ministry of Agriculture at the Sidirokastro Bridge station are water temperature $(\mathrm{T}), \mathrm{pH}$, specific conductivity $(\mathrm{ECw})$, dissolved oxygen (DO), bicarbonates $\left(\mathrm{HCO}_{3}^{-}\right)$, sulphates $\left(\mathrm{SO}_{4}{ }^{2-}\right)$, chlorides $\left(\mathrm{Cl}^{-}\right)$, sodium and potassium $\left(\mathrm{Na}^{+}+\mathrm{K}^{+}\right)$, magnesium $\left(\mathrm{Mg}^{2+}\right)$, calcium $\left(\mathrm{Ca}^{2+}\right)$, nitrate $\left(\mathrm{NO}_{3}^{-}\right)$, ammonia $\left(\mathrm{NH}_{4}^{+}\right)$, total phosphorus (TP) and discharge (Q). The monitoring data for these variables available for the analysis as presented in this paper is on a monthly basis for the period 1980-1997. Discharge is a parameter with many missing values, especially since 1989. It was impossible to complete the values for discharge since 1994 and for this reason, the relationship between discharge and the concentrations and loads were examined only for the period 1980 to 1993. Neither nitrate nor total phosphorus have been measured since 1993. The missing monthly values were completed using the methods proposed by Holder (1985).

\section{Results and discussion}

\section{STATISTICAL ANALYSIS OF WATER QUALITY PARAMETERS AND DISCHARGE}

Figure 2 shows the time series of monthly measured values of $\mathrm{Q}, \mathrm{T}, \mathrm{EC}_{\mathrm{w}}$, concentrations of $\mathrm{DO}, \mathrm{SO}_{4}{ }^{2-}, \mathrm{Na}^{+}+\mathrm{K}^{+}$, $\mathrm{Mg}^{2+} \mathrm{Ca}^{2+}, \mathrm{NO}_{3}^{-}$and $\mathrm{TP}$, at Sidirokastro station. The statistical measures of time series of water quality variables at the Sidirokastro station, used in the following analysis, are given in Table 1. In Table 1, the statistical measures of $\mathrm{pH}, \mathrm{Cl}^{-}, \mathrm{HCO}_{3}^{-}$and $\mathrm{NH}_{4}^{+}$parameters are also given. Many water quality parameters show striking seasonal variations. For temperature and dissolved oxygen, seasonal variation is relatively uniform during the time. There is also a variation in concentrations and discharge. There are different reasons for these variations. Some of them depend on discharge and seasonality; the magnitudes of the fluctuations in discharge are much greater than those of concentrations. The ratio of highest to lowest concentration and water discharge is very large for discharge (214:1) followed by total phosphorus (63:1), sulphate (47:1), temperature (27:1), $\mathrm{Mg}^{2+}(19: 1)$ and $\mathrm{NO}_{3}^{-}$(13.6:1). There is low ratio for $\mathrm{Na}^{+}+\mathrm{K}^{+}(6.5: 1), \mathrm{Ca}^{2+}$ (3.5:1), ECw (3.3:1) and DO (2.4:1). The dominant anion and cation in the water of Strymon river is $\mathrm{HCO}_{3}{ }^{-}$and $\mathrm{Ca}^{2+}$, respectively. The values of $\mathrm{NO}_{3}^{-}$show anthropogenic influence but it is five times less than those in the European rivers in which the medium level of $\mathrm{NO}_{3}^{-}$is $20 \mathrm{mg} \mathrm{l}^{-1}$ (Maybeck et al., 1989). The mean value of phosphorus coincides with the critical value of $0.15 \mathrm{mg} \mathrm{l}^{-1}$ which is considered a minimum requirement for the avoidance of eutrofication effects on European rivers (van Dijk et al., 1994).

A very useful and concise graphical display for summarising the distribution of a data set is the boxplot (Helsel and Hirsch, 1992). Boxplots provide visual 

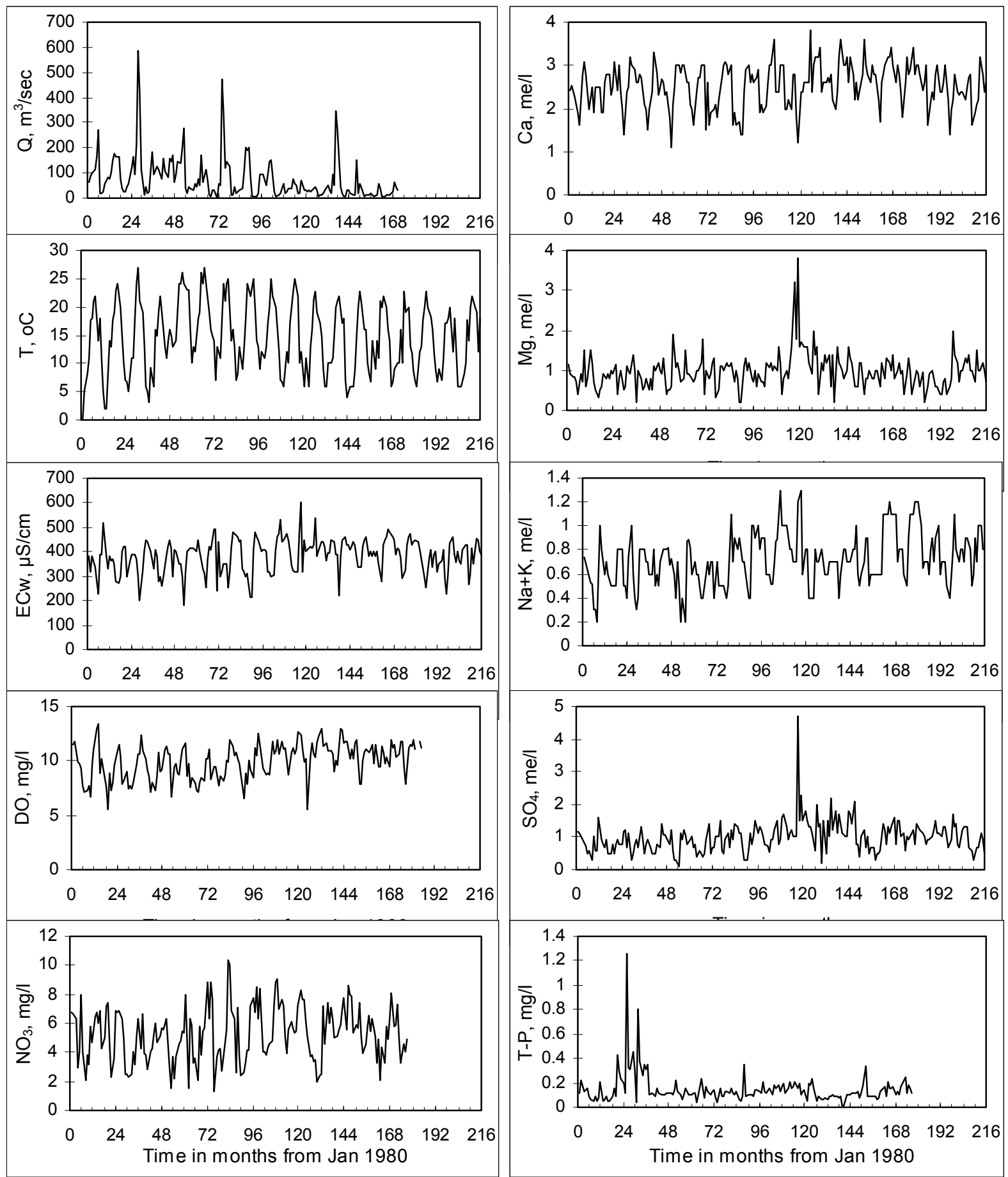

Fig. 2. Time series of water quality parameters and discharge at Sidirokastro station of the Strymon River

summaries of (1) the centre of the data (the median $=$ the centre line of the box), (2) the variation or spread (interquartile range=the box height), (3) the skewness (quartile skew=the relative size of box halves) and (4) presence or absence of unusual values ("outliers" and "extreme" values). Boxplots are even more useful in comparing these attributes between several data sets.
Figure 3 shows the boxplots of water quality parameters and discharge at Sidirokastro station (Mitsiou et al., 1999). The boxplots show that the data of the variables of $\mathrm{Q}, \mathrm{ECW}$, $\mathrm{SO}_{4}^{2-}, \mathrm{Na}^{+}+\mathrm{K}^{+}, \mathrm{Mg}^{2+}, \mathrm{Ca}^{2+}$, and TP depart from a normal distribution not only in skewness, but also by the number of outliers and the extreme values. The data of the variables $\mathrm{DO}$ and $\mathrm{NO}_{3}{ }^{-}$depart from a normal distribution only in the 
Table 1. Statistical parameters of the time series of monthly values of water quality parameters and discharge of the Strymon River at Sidirokastro station.

\begin{tabular}{lllllllll}
\hline Variable & Sample Size & $\overline{\mathrm{x}}$ & $\delta$ & $x_{\max }$ & $x_{\min }$ & $x_{\max }-x_{\min }$ & $s$ & $C V$ \\
\hline $\mathrm{Q}^{2} \mathrm{~m}^{3} \mathrm{sec}^{-1}$ & 171 & 76.43 & 46.00 & 588.87 & 2.75 & 586.12 & 86.96 & 113.77 \\
$\mathrm{~T},{ }^{\circ} \mathrm{C}$ & 216 & 14.65 & 14.00 & 27.00 & 0.00 & 27.00 & 6.14 & 41.87 \\
$\mathrm{ECw}, \mu \mathrm{S} \mathrm{cm}^{-1}$ & 216 & 383.19 & 400.00 & 600.00 & 180.00 & 420.00 & 68.65 & 17.92 \\
$\mathrm{DO}, \mathrm{mg} \mathrm{l}^{-1}$ & 182 & 9.95 & 10.16 & 13.44 & 5.5 & 7.94 & 1.61 & 16.17 \\
$\mathrm{SO}_{4}^{2-}, \mathrm{me} \mathrm{l}^{-1}$ & 216 & 0.99 & 1.00 & 4.70 & 0.10 & 4.60 & 0.46 & 46.73 \\
$\mathrm{Na}^{+}+\mathrm{K}^{+}, \mathrm{me} \mathrm{l}^{-1}$ & 216 & 0.72 & 0.70 & 1.30 & 0.20 & 1.10 & 0.21 & 29.86 \\
$\mathrm{Mg}^{2+}, \mathrm{me} \mathrm{l}^{-1}$ & 216 & 0.97 & 1.00 & 3.80 & 0.20 & 3.60 & 0.43 & 44.79 \\
$\mathrm{Ca}^{2+}, \mathrm{me} \mathrm{l}^{-1}$ & 216 & 2.52 & 2.60 & 3.80 & 1.10 & 2.70 & 0.50 & 19.81 \\
$\mathrm{NO}_{3}^{-}, \mathrm{mg} \mathrm{l}^{-1}$ & 177 & 5.25 & 5.28 & 10.34 & 0.76 & 9.58 & 1.88 & 35.81 \\
$\mathrm{TP}^{-} \mathrm{mg} \mathrm{l}^{-1}$ & 177 & 0.15 & 0.12 & 1.26 & 0.02 & 1.24 & 0.12 & 83.90 \\
$\mathrm{pH}^{-1}$ & 215 & 7.79 & 7.85 & 8.5 & 6.9 & 1.6 & 0.37 & 4.75 \\
$\mathrm{Cl}^{-}, \mathrm{me} \mathrm{l}^{-1}$ & 215 & 0.25 & 0.2 & 0.8 & 0.1 & 0.7 & 0.15 & 60.00 \\
$\mathrm{HCO}_{3}^{-}, \mathrm{me} \mathrm{l}^{-1}$ & 215 & 2.92 & 3.0 & 4.2 & 1.3 & 2.9 & 0.59 & 20.21 \\
$\mathrm{NH}_{4}^{+}, \mathrm{mg} \mathrm{l}^{-1}$ & 110 & 0.113 & 0.086 & 0.56 & $0.025^{* *}$ & & & \\
\hline
\end{tabular}

Notes on the table: $\overline{\mathrm{X}}$ : mean, $\delta$ : median, $\mathrm{x}_{\max }$ : maximum value, $\mathrm{x}_{\min }:$ minimum value, $\mathrm{s}$ : standard deviation, $\mathrm{CV}$ : coefficient of variation, ${ }^{* *}$ Lower detection limit.

skewness. It is noted that only temperature is approaching normality. Figure 3 shows that there are many outliers and extreme values for the variables of $\mathrm{Q}, \mathrm{SO}_{4}^{2-}, \mathrm{Mg}^{2+}$, and $\mathrm{TP}$. The extreme values of $Q$ are due to floods, while the extreme values of other variables are unexpected and maybe due to non-suitable measurements or handling the water samples.

The procedure used to fit a theoretical continuous distribution function to the data time series (a) provides the parameter estimates for the chosen distribution function, (b) calculates a chi-square statistic that allows comparison of observed and expected frequencies, with its degrees of freedom (d.f.) at a chosen significant level of $\alpha=0.05$, (c) runs a Kolmogorov-Smirnov one-sample test for goodnessof-fit with its maximum absolute deviation (D) and (d) plots a frequency histogram with the fitted distribution superimposed on it (Statgraphics, 1987). Table 2 includes the results of the aforementioned procedure for the water variables of the Strymon River. It has been accepted that the best fitted theoretical distribution to each data time series is the one which satisfies both tests $\left(\chi^{2}\right.$-test and K-S test).

Table 2. The best-fitted distribution parameters and the values of the goodness-of-fit tests

\begin{tabular}{|c|c|c|c|c|c|c|}
\hline \multirow[t]{2}{*}{ Variable } & \multirow[t]{2}{*}{ Distribution } & \multicolumn{2}{|c|}{ Distribution parameters } & \multicolumn{2}{|c|}{$\chi^{2}$-test } & \multirow{2}{*}{$\begin{array}{l}K-S \text {-test } \\
\mathrm{D}\end{array}$} \\
\hline & & & & $\chi^{2}$ & d. $f$. & \\
\hline $\mathrm{Q}, \mathrm{m}^{3} \mathrm{sec}^{-1}$ & Weibull & $\alpha: 0.9955$ & $\beta: 76.269$ & 2.635 & 4 & 0.0748 \\
\hline $\mathrm{T},{ }^{\circ} \mathrm{C}$ & Normal & $\mu: 14.6545$ & $\sigma: 6.13597$ & 36.9328 & 12 & 0.0755 \\
\hline $\mathrm{ECw}, \mu \mathrm{S} \mathrm{cm}{ }^{-1}$ & Weibull & $\alpha: 6.43361$ & $\beta: 410.991$ & 10.3065 & 9 & 0.0796 \\
\hline $\mathrm{DO}, \mathrm{mg} \mathrm{l}$ & Weibull & $\alpha: 7.31446$ & $\beta: 10.6215$ & 11.0878 & 8 & 0.0542 \\
\hline $\mathrm{SO}_{4}^{2-}, \mathrm{me}^{-1}$ & Gamma & $\alpha: 5.09018$ & $\beta: 5.12012$ & 4.44135 & 3 & 0.07735 \\
\hline $\mathrm{Na}^{+}+\mathrm{K}^{+}, \mathrm{me}^{-1}$ & Weibull & $\alpha: 3.64018$ & $\beta: 0.79519$ & 13.5527 & 7 & 0.119063 \\
\hline $\mathrm{Mg}^{2+}, \mathrm{me}^{-1}$ & Logistic & $\mu: 0.944792$ & $\sigma: 0.39549$ & 9.34 & 2 & 0.08544 \\
\hline $\mathrm{Ca}^{2+}, \mathrm{me} \mathrm{l}^{-1}$ & Weibull & $\alpha: 5.88114$ & $\beta: 2.72124$ & 9.476 & 8 & 0.07423 \\
\hline $\mathrm{NO}_{3}^{-}, \mathrm{mg} \mathrm{l}^{-1}$ & Weibull & $\alpha: 3.07478$ & $\beta: 5.87368$ & 6.8811 & 9 & 0.04016 \\
\hline $\mathrm{TP}, \mathrm{mg} \mathrm{l}^{-1}$ & LogNormal & $\mu: 0.143282$ & $\sigma: 0.08597$ & 15.389 & 4 & 0.092852 \\
\hline
\end{tabular}



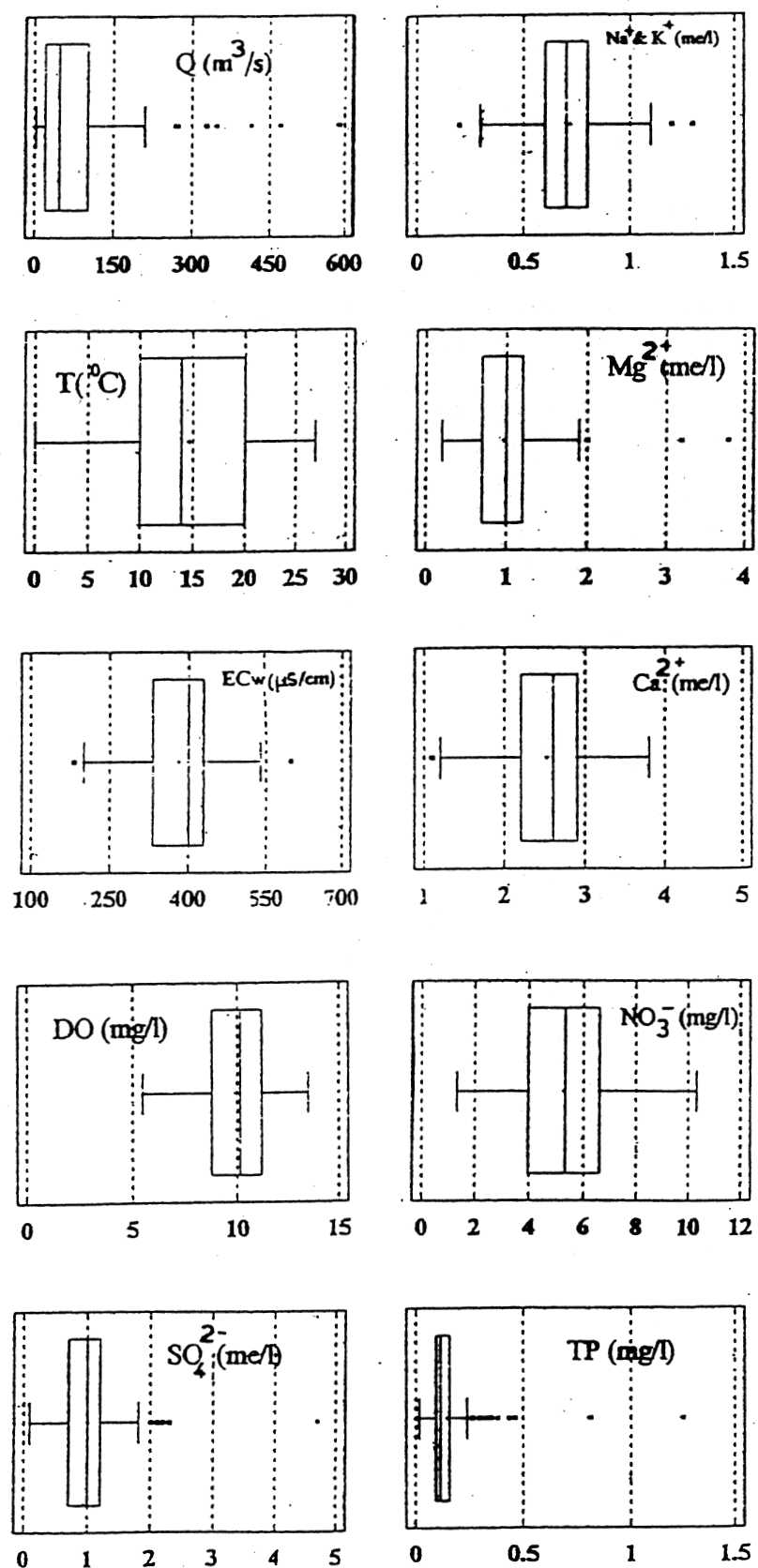

Fig. 3. Boxplots of measured values of water quality parameters and discharge at Sidirokastro station of the Strymon River

Figure 4 shows the frequency histograms of the data time series with the best fitted distributions.

After a thorough examination of the statistical tests' parameter values the following conclusions about the distribution of each variable were reached: the Strymon's discharge follows the Weibull distribution. The specific conductivity, the dissolved oxygen, the $\mathrm{Ca}^{2+}$ and the nitrate also follow the Weibull distribution. The sulphates follow the Gamma distribution. Water temperature, $\mathrm{Mg}^{2+}$ and total phosphorus approach none of the known theoretical distributions according to both goodness-of-fit criteria. According to the $\mathrm{K}-\mathrm{S}$ test only, water temperature approaches the normal distribution, $\mathrm{Mg}^{2+}$ the logistic and total phosphorus the lognormal. According to the $\chi^{2}$-test only $\mathrm{Na}^{+}+\mathrm{K}^{+}$follows the Weibull distribution.

\section{CONCENTRATION- DISCHARGE AND LOAD- \\ DISCHARGE RELATIONSHIPS}

The results of simple regression applied between each water quality variable's concentration (dependent variable) and the discharge (independent variable) as well as between each water quality variable's load (dependent variable) and the discharge (independent variable), monitored at the Sidirokastro station of the Strymon River are given in Table 3 . In this table the values parameters $a$ and $b$ of linear $\left(\mathrm{C}_{\mathrm{ij}}=\mathrm{a}+\mathrm{b} \mathrm{Q}_{\mathrm{j}}\right)$, power $\left(\mathrm{C}_{\mathrm{ij}}=\mathrm{aQ} \mathrm{Q}_{\mathrm{j}}^{\mathrm{b}}\right)$, exponential $\left(\mathrm{C}_{\mathrm{ij}}=\mathrm{a} \exp \left(\mathrm{b} \mathrm{Q}_{\mathrm{j}}\right)\right)$, and logarithmic $\left(\mathrm{C}_{\mathrm{ij}}=\mathrm{a}+\mathrm{b} \ln \left(\mathrm{Q}_{\mathrm{j}}\right)\right)$ models as well as the correlation coefficients are given. Figures 5 and 6 show the best-fitted to the data regression models. From the values of Table 3 and the graphs of Figs. 5 and 6 it is clear that: (a) no one of the applied models describes well the concentration-discharge relationships or these relationships are very weak, (b) the correlation coefficients are negative for most of the variables, except nitrates and total phosphorus, which show a decreasing relationship. This is a result (Edwards, 1973) of dilution effects of surface runoff, during periods of high runoff in the catchment, on the water of base runoff, (c) the logarithmic and the power models describe better the concentration-discharge relationships, and d) the relationship between conductivity (which express the total dissolved solids) and discharge, has got the better correlation coefficient value $(\mathrm{r}=-0.592)$, following by Calcium $(\mathrm{r}=-0.553)$ and then by the other cations $\mathrm{Na}^{+}+\mathrm{K}^{+}$ $(\mathrm{r}=-0.466)$ and $\mathrm{Mg}^{2+}(\mathrm{r}=-0.384)$, while dissolved oxygen, total phosphorus and nitrates show weaker relations.

The load-discharge relationships show better correlation than that of concentration-discharge. The power model expresses better the load-discharge relationships. The correlation coefficients are very high: $r=0.903$ and $r=0.981$ for the cations $\mathrm{Mg}^{2+}$ and $\mathrm{Ca}^{2+}$, respectively and $\mathrm{r}=0.941$ and $\mathrm{r}=0.902$ for nitrates and total phosphorus, respectively. The slope coefficient $b$ (Table 3 ) for nitrate and phosphorus discharge-load relationships are greater than 1.0. The concentrations of these constituents have a fairly good positive correlation with discharge (Edwards, 1973). The dilution effects of high discharges on concentration produces lower values for coefficient $b$. The smaller value of $b$ is 0.83 for $\mathrm{Mg}^{2+}$, followed by 0.89 for $\mathrm{Ca}^{2+}$.

Discharge has strong seasonality with the higher values during the spring as a result of snow melting from the 

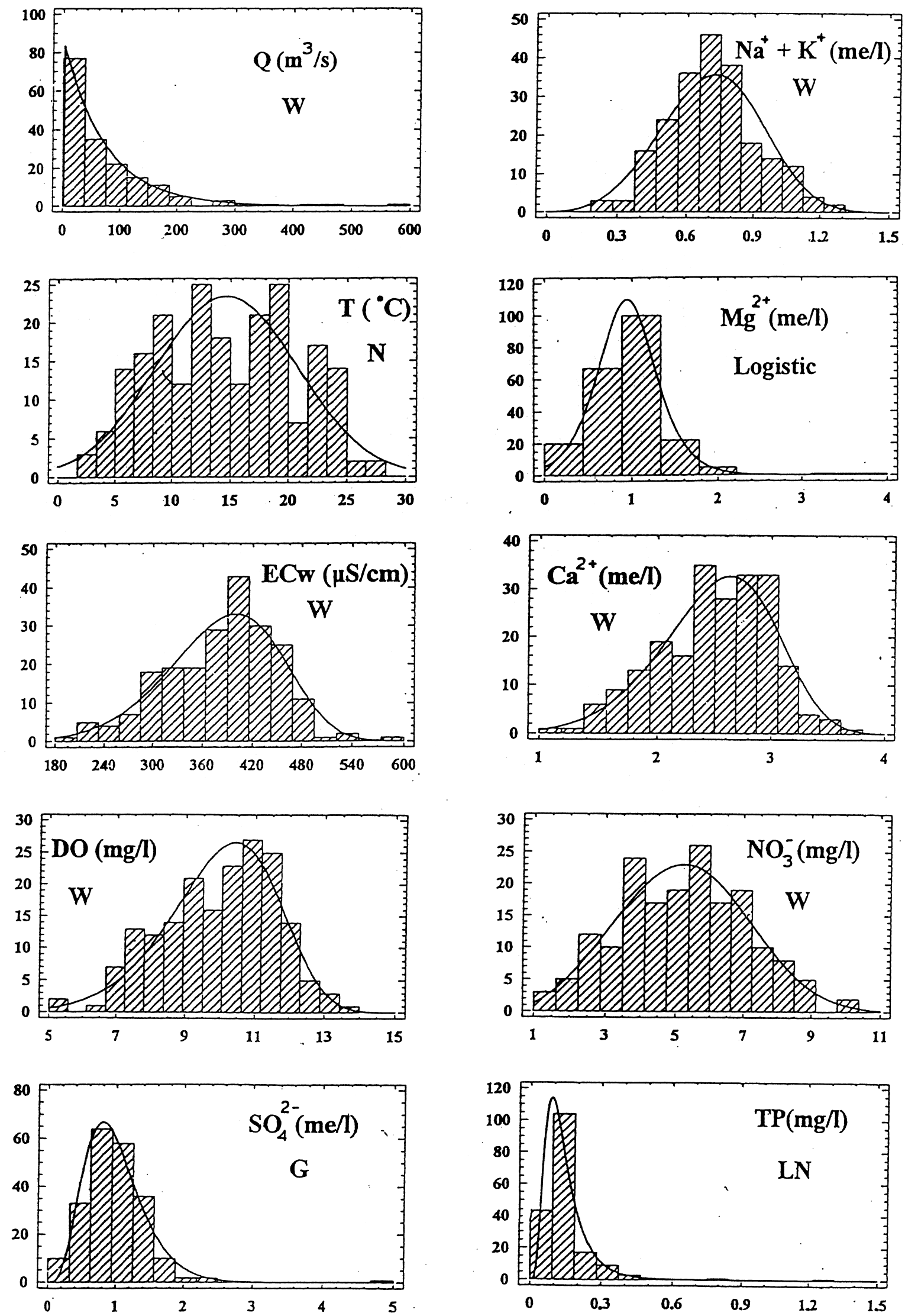

Fig. 4. Frequencies of monthly measured values of water quality parameters and discharge with the best fitted theoretical distribution 

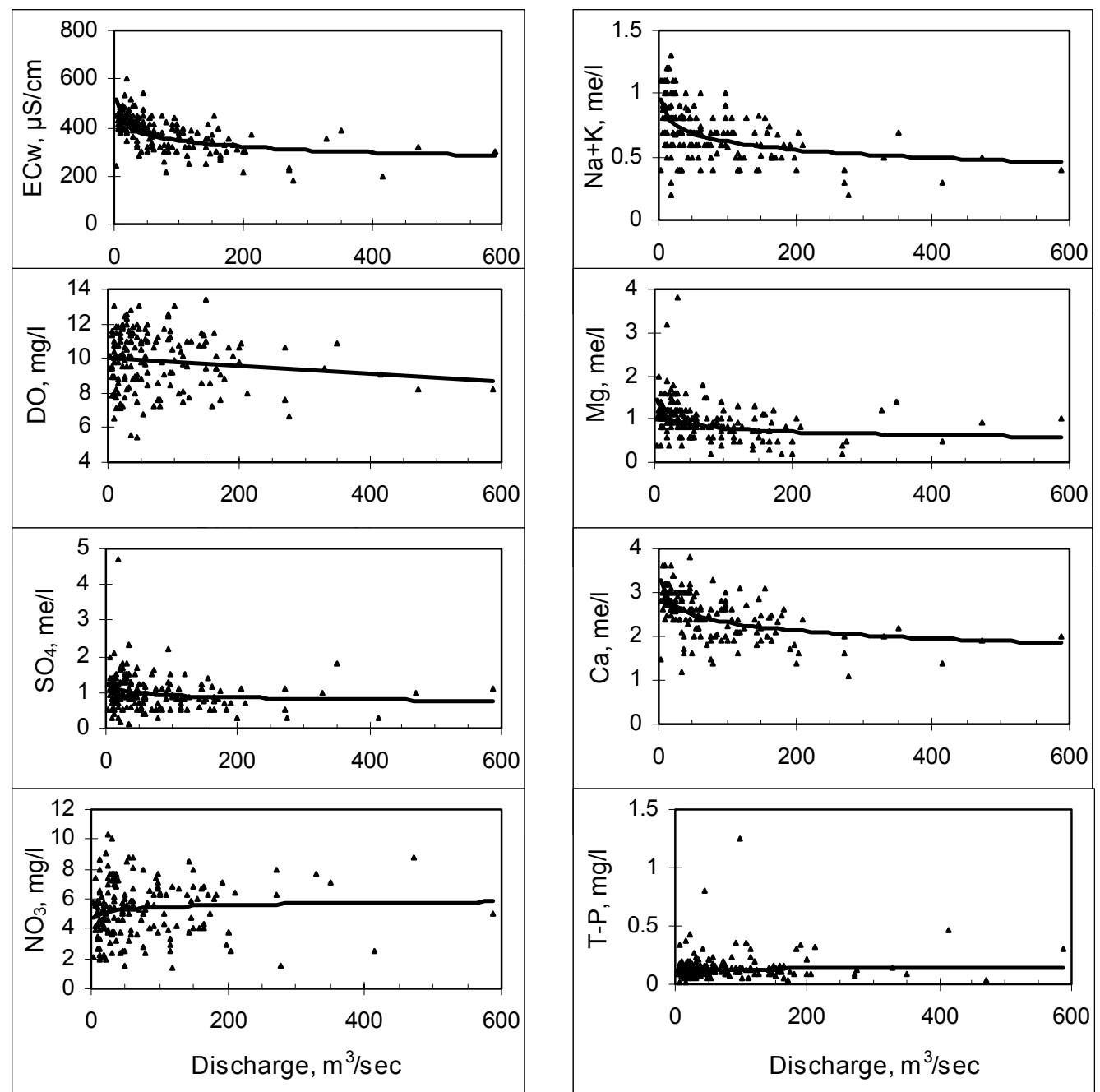

Fig. 5. Concentration of water quality parameters against discharge relationships with the curve of the best fitted model.

Table 3. Concentration-discharge and load-discharge relationships

\begin{tabular}{|c|c|c|c|c|c|c|c|c|c|}
\hline \multicolumn{5}{|c|}{ Concentration-discharge } & \multicolumn{5}{|c|}{ Load-discharge } \\
\hline Variable & Equation & $\mathrm{a}$ & $b$ & $r$ & Variable & Equation & $\mathrm{a}$ & $b$ & $r$ \\
\hline $\mathrm{ECw}, \mu \mathrm{S}$ & Power & 573.39 & -0.1101 & -0.592 & & & & & \\
\hline $\mathrm{DO}, \mathrm{mg} \mathrm{l}^{-1}$ & Linear & 10.07 & -0.0023 & -0.123 & $\mathrm{DO}, \operatorname{tn} \mathrm{d}^{-1}$ & Power & 0.8635 & 0.9936 & 0.987 \\
\hline $\mathrm{SO}_{4}^{2-}, \mathrm{me}^{-1}$ & $\log$ & 1.3267 & -0.0883 & -0.190 & $\mathrm{SO}_{4}^{2-}, \operatorname{tn~d}^{-1}$ & Power & 5.0192 & 0.9173 & 0.895 \\
\hline $\mathrm{Na}^{+}+\mathrm{K}^{+}, \mathrm{me} \mathrm{l}^{-1}$ & $\log$ & 1.0428 & -0.0918 & -0.466 & & & & & \\
\hline $\mathrm{Mg}^{2+}, \mathrm{me}^{-1}$ & Power & 1.6882 & -0.1651 & -0.384 & $\mathrm{Mg}^{2+}$, tn $\mathrm{d}^{-1}$ & Power & 1.7732 & 0.8349 & 0.903 \\
\hline $\mathrm{Ca}^{2+}, \mathrm{me} \mathrm{l}^{-1}$ & $\log$ & 3.5294 & -0.263 & -0.553 & $\mathrm{Ca}^{2+}$, tn $\mathrm{d}^{-1}$ & Power & 6.5012 & 0.8898 & 0.981 \\
\hline $\mathrm{NO}_{3}^{-}, \mathrm{mg} \mathrm{l}^{-1}$ & $\log$ & 4.5466 & 0.1961 & 0.113 & $\mathrm{NO}_{3}^{-}$, tn $\mathrm{d}^{-1}$ & Power & 0.3717 & 1.0354 & 0.941 \\
\hline $\mathrm{TP}, \mathrm{mg}^{-1}$ & Power & 0.0916 & 0.0746 & 0.144 & $\mathrm{TP}, \mathrm{tn} \mathrm{d}^{-1}$ & Power & 0.0079 & 1.0746 & 0.902 \\
\hline
\end{tabular}

mountainous area of the catchment. The seasonality in discharge and the inverse relationships with the solutes of $\mathrm{Ca}^{2+}$ and $\mathrm{Mg}^{2+}$, which have groundwater sources and
$\mathrm{Na}^{+}+\mathrm{K}^{+}$, which have predominantly point sources, controls the patterns of these solutes. TP and $\mathrm{NO}_{3}$ show no welldefined seasonal patterns with very highly scattered 

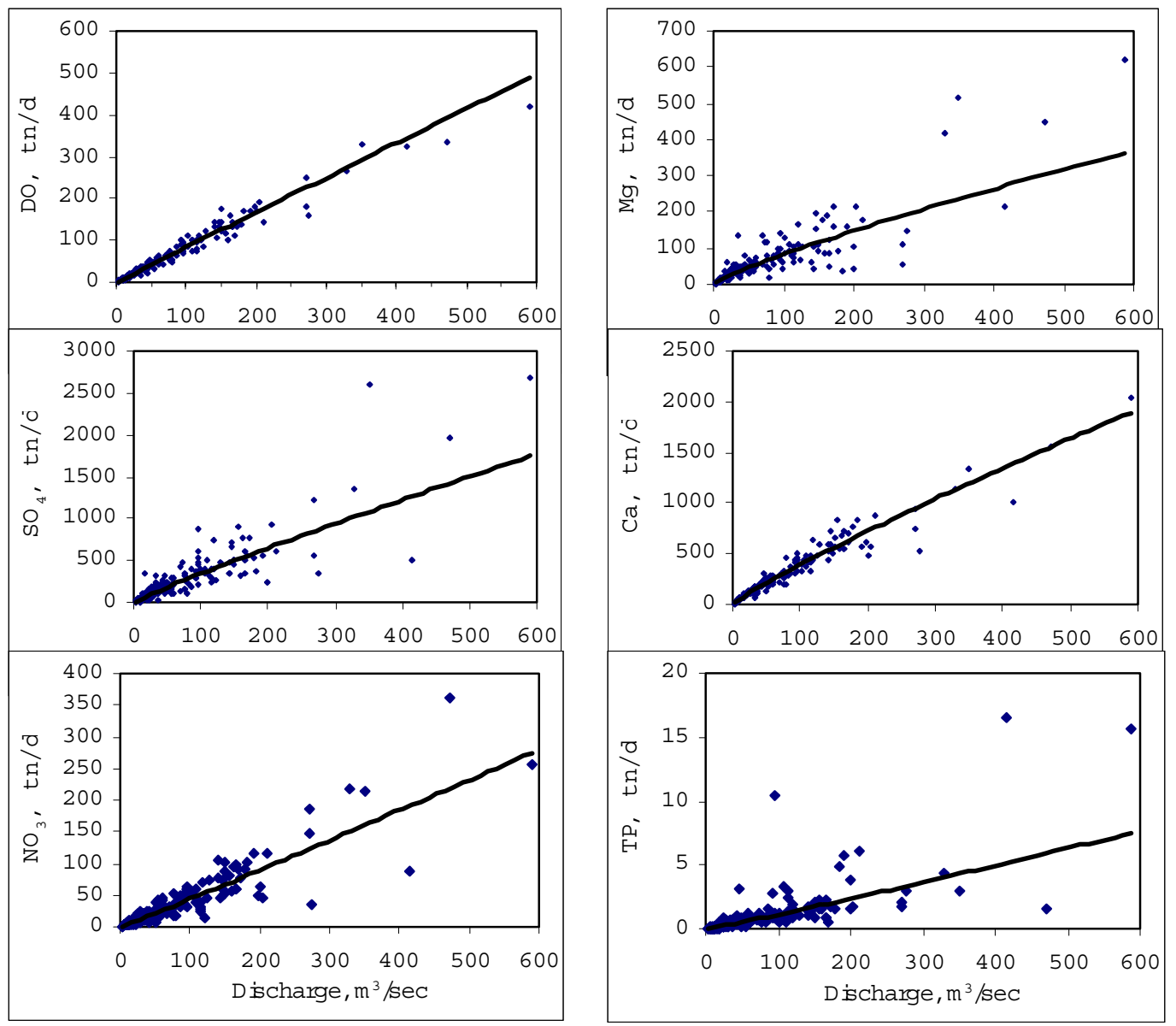

Fig. 6. Load of water quality parameters against discharge relationships with the curve of the best fitted model.

relationships with the water discharge, indicating the existence of many different potential sources and availability of sources for transportation within the river system.

\section{TREND ANALYSIS OF WATER QUALITY}

\section{PARAMETERS}

The time series of nine water quality parameters and the discharge of the Strymon River at the Sidirokastro station were tested for existence of trend, by using the nonparametric Spearman's criterion and analysed by fitting different trend models. The value of Spearman's rankcorrelation coefficient (Eqn. 3), the Spearman statistical criterion (Eqn. 4) and the limits defined by Eqn. (5), which for $\mathrm{n}=216$ (18 years*12 months), is: $\mathrm{t}\{214,2.5 \%\}<\mathrm{t}_{\mathrm{t}}<$ $\mathrm{t}\{214,97.5 \%\}$, where: $\mathrm{t}\{214,2.5 \%\}=-1.96$ and $\mathrm{t}\{214,97.5 \%\}=1.96$, for the examined time series are given in Table 4. So, according to the results of Spearman's test (Table 4), the values of the given series of observations of $\mathrm{Q}, \mathrm{ECw}, \mathrm{DO}, \mathrm{SO}_{4}^{2+}, \mathrm{Na}^{+}+\mathrm{K}^{+}$and $\mathrm{NO}_{3}{ }^{-}$changed over time in a certain rate. In order to describe these changes an attempt was made to fit one of the known trend models (Eqns. 6-9) to each data time series. The selection of the "best-fitted" model was based on the values of the statistical tests described by Eqns. 10-12 and are given in Table 5, while

Table 4. Detecting trend existence in Strymon's water quality variables

\begin{tabular}{lrrl}
\hline Variable & \multicolumn{2}{l}{ Sidirokastro station } & \multicolumn{2}{l}{$\begin{array}{l}\text { Is there a } \\
\text { trend? }\end{array}$} \\
& \multicolumn{1}{c}{$R_{s p}$} & \multicolumn{1}{c}{$t_{t}$} & \\
\hline $\mathrm{Q}, \mathrm{m}^{3} \mathrm{sec}^{-1}$ & -0.4940 & -7.386 & Yes \\
$\mathrm{ECW}, \mu \mathrm{S} \mathrm{cm}^{-1}$ & 0.1885 & 2.808 & Yes \\
$\mathrm{DO}, \mathrm{mg} \mathrm{l}^{-1}$ & 0.4145 & 6.111 & Yes \\
$\mathrm{SO}_{4}^{2-}, \mathrm{me} \mathrm{l}^{-1}$ & 0.2657 & 4.031 & Yes \\
$\mathrm{Na}^{+}+\mathrm{K}^{+}, \mathrm{me} \mathrm{l}^{-1}$ & 0.3324 & 5.156 & Yes \\
$\mathrm{Mg}^{2+}, \mathrm{me} \mathrm{l}^{-1}$ & 0.1106 & 1.628 & No \\
$\mathrm{Ca}^{2+}, \mathrm{me} \mathrm{l}^{-1}$ & 0.1311 & 1.935 & No \\
$\mathrm{NO}_{3}^{-}, \mathrm{mg} \mathrm{l}^{-1}$ & 0.1551 & 2.077 & Yes \\
$\mathrm{TP} \mathrm{mg} \mathrm{l}^{-1}$ & -0.0475 & -0.629 & No \\
\hline
\end{tabular}



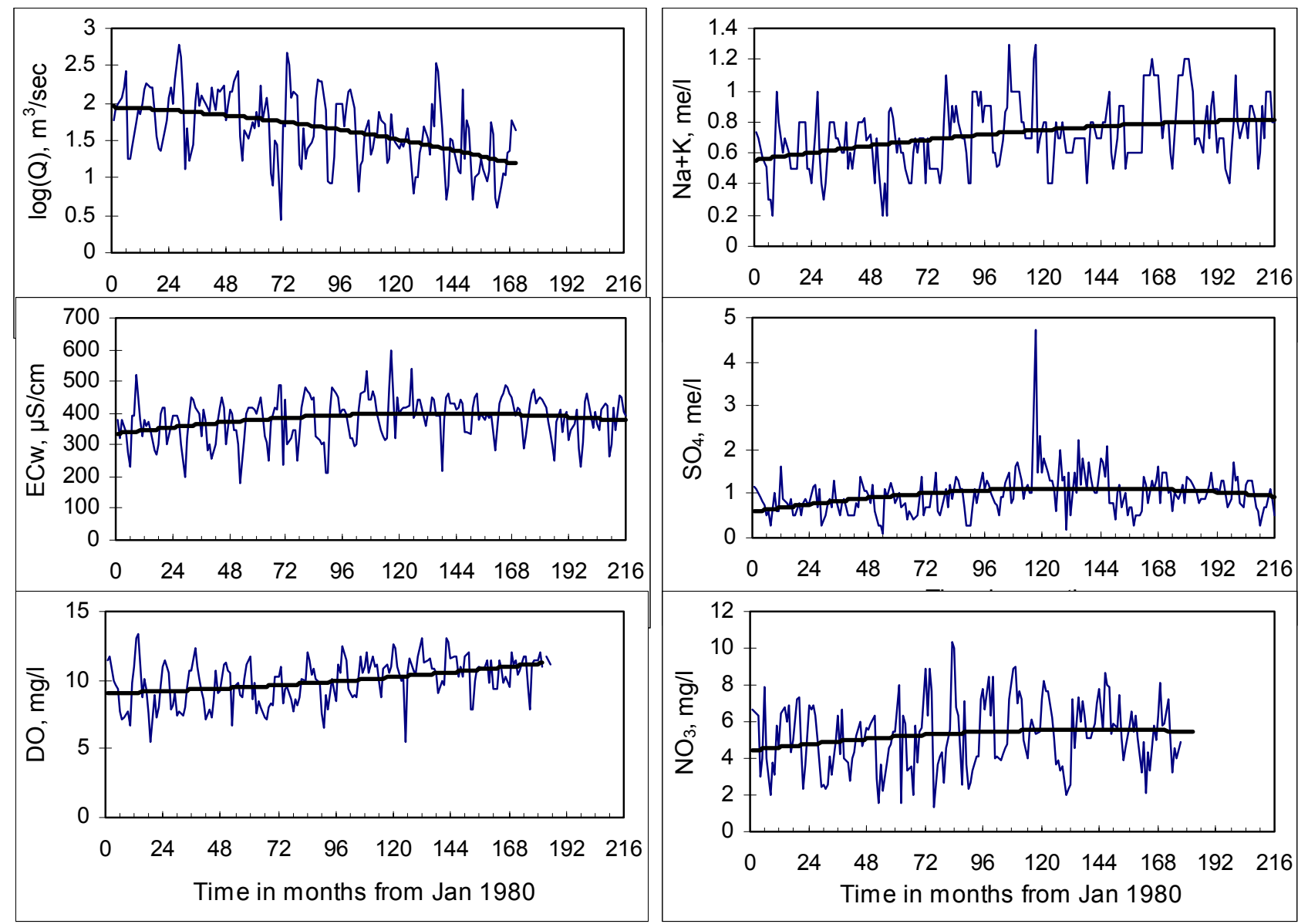

Fig. 7. Monthly measured values of water quality parameters and discharge and the curves of the best fitted trend model.

their graphs, along with the observed values of the data time series, are shown in Fig. 7 (Mitsiou et al., 2000).

The conclusions deriving from the previous trend analysis are: (a) the second order equation (Eqn. 7) describes the trend of the data time series better, (b) the trend of discharge (Q) is downwards, while the trends of the water quality variables $\left(\mathrm{ECW}\right.$ and concentration of $\mathrm{DO}, \mathrm{SO}_{4}^{2-}, \mathrm{Na}^{+}+\mathrm{K}^{+}$ and $\mathrm{NO}_{3}^{-}$) are upwards, and c) the concentrations of $\mathrm{Ca}^{2+}$,
$\mathrm{Mg}^{2+}$ and TP have no trends.

The downward trend of discharge in relation to the relatively high inverse relationship with $\mathrm{ECw}$ and $\mathrm{Na}^{+}+\mathrm{K}^{+}$ (Table 3) has affected the trend of these variables. The decrease in discharge causes increase in these variables, while the weak relationship of discharge with $\mathrm{DO}, \mathrm{SO}_{4}{ }^{2-}$, $\mathrm{NO}_{3}{ }^{-}$and $\mathrm{TP}$ does not influence the trend of these variables.

The year 1989 was a very significant historical year in

Table 5. Trend models which describe better the trends of the Strymon's water quality variables, with the values of the statistical tests for the goodness-of-fit

\begin{tabular}{llllll}
\hline Variable & Model & ME & MSE & MAE & \multirow{2}{*}{ MAPE } \\
\hline Log Q & $4.49932-3.42274 \mathrm{E}-3 * \mathrm{~T}-4.08985 \mathrm{E}-5 * \mathrm{~T}^{2}$ & 0.00 & 0.88218 & 0.74856 & 23.8301 \\
$\mathrm{ECw}$ & $334.772+0.953291 * \mathrm{~T}-3.51276 \mathrm{E}-3 * \mathrm{~T}^{2}$ & 0.00 & $4,399.69$ & 53.1991 & 15.5431 \\
$\mathrm{DO}$ & $9.04276+5.59813 \mathrm{E}-3 * \mathrm{~T}+3.55885 \mathrm{E}-5 * \mathrm{~T}^{2}$ & 0.00 & 2.1618 & 1.18056 & 12.7407 \\
$\mathrm{SO}_{4}^{2-}$ & $0.588238+7.95705 \mathrm{E}-3 * \mathrm{~T}-2.92094 \mathrm{E}-5 * \mathrm{~T}^{2}$ & 0.00 & 0.19436 & 0.30573 & 43.8443 \\
$\mathrm{Na}^{+}+\mathrm{K}^{+}$ & $0.553699+2.13343 \mathrm{E}-3 * \mathrm{~T}-4.31444 \mathrm{E}-6 * \mathrm{~T}^{2}$ & 0.00 & 0.03990 & 0.16147 & 26.6884 \\
$\mathrm{NO}_{3}^{-}$ & $4.4258+0.015875 * \mathrm{~T}-5.60225 \mathrm{E}-5 * \mathrm{~T}^{2}$ & 0.00 & 3.41646 & 1.51484 & 39.6041 \\
\hline
\end{tabular}


the countries of upstream boundaries of Greece. It was the year with very drastic changes in the political status of Bulgaria and FYROM. The transition from the socialist to the free market status influenced the development of these countries. It is very important to study the trends in the flow and water quality of the Strymon river entering Greece during these two special periods: before the political change and after it. The examination of time series for the period of 1980 to 1989 shows that, except discharge, all the other parameters presented an upward trend. The explanation, in relation to the political status, is that the countries were in a development stage and they were likely to use the water from the river and to produce solutes that pollute the river. During the last period (1990-1997) the upstream countries have been under a stagnation and retardation growth status by stopping or reversing productivity, especially during the first years of the decade. The time series during this period show a continuous decrease in discharge, $\mathrm{ECW}$ and $\mathrm{NO}_{3}$, while there is an increase in the $\mathrm{DO}, \mathrm{Na}^{+}+\mathrm{K}^{+}$and $\mathrm{SO}_{4}{ }^{2-}$.

\section{Conclusions}

Data of water quality variables and discharge at the Sidirokastro station of the transboundary Strymon River in its Greek part were analysed using statistical methods and trend analysis. The time series of monthly measured values of six water quality variables $\left(\mathrm{ECw}, \mathrm{T}, \mathrm{SO}_{4}{ }^{2-}, \mathrm{Na}^{+}+\mathrm{K}^{+}, \mathrm{Mg}^{2+}\right.$ and $\mathrm{Ca}^{2+}$ ) over 18 years (1980-1997), and the discharge (Q), DO, $\mathrm{NO}_{3}^{-}$and TP over 14 years (1980-1993) are used for this analysis.

The statistical analysis of aforementioned variables resulted that according to the $\mathrm{K}-\mathrm{S}$ and $\chi^{2}$ tests, discharge, specific conductivity, dissolved oxygen, $\mathrm{Ca}^{2+}$ and the nitrate follow the Weibull distribution, while sulphates follow the Gamma distribution. According to the K-S test only, water temperature approaches the normal distribution, $\mathrm{Mg}^{2+}$ the logistic and total phosphorus the Lognormal, while $\mathrm{Na}^{+}+\mathrm{K}^{+}$ follows the Weibull distribution according to the $\chi^{2}$-test only.

Seasonal variations in stream water chemistry are strongly related to discharge variations. However, the solute concentrations were related weakly with the discharge although the solute loads were related very strongly with the discharge.

The nonparametric Spearman's criterion was used to analyse for trends in the water quality variables and discharge time series, for the period 1980 to 1997 . The Spearman's test detected trends in discharge, dissolved oxygen, conductivity, sulphate, sodium, potassium and nitrate. The second order equation provided a better description of variables for which trends were detected.
Discharge was the only variable which showed a downward trend.

\section{Acknowledgements}

The authors wish to thank the Department of Irrigation and Water Protection of Greek Ministry of Agriculture for providing the water quality and discharge monitoring data for the Strymon River.

\section{References}

Antonopoulos, V. and Papamichail, D., 1991. Stochastic analysis of water quality parameters in streams, In: Water Resources Management and Technology, G. Tsakiris (Ed.).Balcema, 369376.

Dahmen, E.R. and Hall, M.J., 1990. Screening of Hydrological Data: Tests for Stationarity and Relative Consistency, ILRI Publication No.49, Wageningen, The Netherlands.

Edwards, A.M.C., 1973. The variation of dissolved constituents with discharge in some Norfolk rivers, J. Hydrol., 18, 219-242.

European Community, 1994. Water Quality of Surface WatersCommon procedure for exchange of information. General Direction XI, Environment, nuclear safety and public protection.

Ferrier, R.C., Edwards, A.C., Hirst, D., Littlewood, I.G., Watts, C.D. and Morris, R., 2001. Water quality of Scottish rivers: spatial and temporal trends, Sci. Total Envir., 265, 327-342.

Haan, C.T., 1977. Statistical methods in hydrology. The Iowa University Press, Iowa, U.S.A.

Helsel, D.R. and Hirsch, R.M., 1992. Statistical Methods in Water Resources. Elsevier, The Netherlands.

Hirsch, R.M. and Slack, J.R., 1984. A nonparametric trend test for seasonal data with serial dependence, Water Resour. Res., 20, 727-732.

Hirsch, R.M., Slack, J.R. and Smith, R.A., 1982. Techniques of trend analysis for monthly water quality data, Water Resour. Res. 18, 107-121.

Hirsch, R. M., Alexander, R.B. and Smith, R.A., 1991. Selection of methods for the detection and estimation of trends in water quality, Water Resour. Res., 27, 803-813.

Holder, R.L., 1985. Multiple regression in Hydrology. Institute of Hydrology, Wallingford, UK. 147pp.

Larsen, S.E., Kronvang, B., Windolf, J. and Svendsen, L.M., 1999. Trends in diffuse nutrient concentrations and loading in Denmark: Statistical trend analysis of stream monitoring data, Water. Sci. Technol., 39, 197-205.

Lettenmaier, R.P., Hooper, E.R., Wagoner, C., and Fans, K.B., 1991. Trends in stream quality in continental United States, 1978-1987, Water Resour. Res., 27, 327-339.

Liebetrau, A.M., 1979. Water quality sampling: some statistical considerations, Water Resour. Res., 15, 1717-1728.

Littlewood, I.G., Watts, C.D. and Custance, J.M., 1998. Systematic application of United Kingdom river flow and quality databases for estimating annual river mass loads (1975-1994), Sci. Total Envir, 210, 21-40.

Makridakis, S., Wheelwright, S.C. and Megee, V.E., 1986. Forecasting: Methods and Application, $2^{\text {nd }}$ edition. Wiley, New York.

Maybeck, M., Chapman, D. and Helmer, R., 1989. Global Freshwater Quality - A First assessment, WHO and UNEP, Blackwell Ltd., U.S.A., 306 pp. 
Miller J.D. and Hirst, D., 1998. Trends in concentrations of solutes in an upland catchment in Scotland, Sci. Total Envir., 216, 7788.

Mitsiou, K., Antonopoulos, V. and Papamichail, D., 1999. Statistical analysis of water quality parameters time series of Strymon river, Hydrotechnika, 9, 59-74 (in Greek)

Mitsiou, K., Antonopoulos, V. and Papamichail, D., 2000. Trend analysis of water quality parameters of Strymon river. Proceedings of $8^{\text {th }}$ conference of Hellenic Hydrotechnical Chamber (EYE), Athens, 259-266 (in Greek).

Oborne, A.C., Brooker, M.P. and Edwards, R.W., 1980. The chemistry of the River Wye, J. Hydrol., 45, 233-252.
Pinol, J., Avila, A. and Roda, F., 1992. The seasonal variation of steamflow chemistry in three forested Mediterranean catchments, J. Hydrol., 140, 119-141.

Statgraphics, 1987. User's Guide. Statistical Graphics Corporation, S.T.S.C., Inc., USA.

van Dijk, G.M., van Liere, L., Amiraal, W., Bannink, B.A. and Cappon, J.J., 1994. Present state of the water quality of European rivers and implications for management, Sci. Total Envir., 145, $187-195$. 
